\title{
SACERDÓCIO REAL: DOM DE DEUS PARA CONSTITUIR UM POVO SACERDOTAL
}

Prof. Dr. Valeriano dos Santos Costa*

\section{RESUMO}

Começam, em 2012, as comemorações dos cinquenta anos do início do Concílio Vaticano II. É necessário salientar as grandes conquistas que esse Concílio trouxe para a Igreja e para a humanidade. Entre estas, destaca-se a eclesiologia Povo de Deus e, em decorrência, o conceito de sacerdócio real ou sacerdócio "comum de todos os fiéis" por graça do batismo, que por séculos desapareceu da reflexão eclesial. O sacerdócio real, ao seu modo, participa do único sacerdócio de Cristo e constitui o patamar para se falar de uma Igreja sacerdotal e toda ministerial. Então, o povo da Nova Aliança é um povo sacerdotal.

Palavras-chave: Povo sacerdotal. Serviço. Participação. Cristo Sumo Sacerdote. Nova Aliança.

\section{ABSTRACT}

We begin, in 2012, the celebrations of the 50 years since the beginning of Vatican II. It should be noted the great achievements that the Council brought to the Church and for humanity. Among these, it is noteworthy the ecclesiology People of God and as a result, the concept of royal priesthood or priesthood "common of all the faithful" by grace of baptism, who for centuries, disappeared from ecclesial reflection. The royal priesthood, in its way, participates of the one priesthood of Christ and forms the basis for if you speak of a church priestly and all ministry. And the people of the New Covenant, is a priestly people.

Keyword: Priestly people. Service. Participation. Christ the High Priest. New alliance.

\footnotetext{
* Professor da Faculdade de Teologia Nossa Senhora da Assunção, da PUC-SP. Doutor em Sagrada Liturgia pelo Pontifício Instituto Litúrgico Sant'Anselmo, Roma. Desenvolve pesquisa sobre a sacramentalidade da liturgia.
} 


\title{
INTRODUÇÃO
}

O tema do sacerdócio real de todos os batizados é muito presente na eclesiologia do Concílio Vaticano II. E é muito atual nos dias de hoje, quando somos convidados a refletir, cinquenta anos depois do Concílio, sobre a necessidade de a Igreja avançar para as águas mais profundas da evangelização.

Nessa perspectiva, vai acontecer a $13^{a}$ Assembléia Geral Ordinária do Sínodo dos Bispos, em outubro de 2012, em Roma, justamente quando comemoramos cinquenta anos do início do Concilio. $\mathrm{E}$ o mais interessante é o tema: A nova Evangelização para a transmissão da fé cristã.

Para se chegar a uma nova evangelização que responda a contento pela transmissão da fé hoje, urge que todos os cristãos, pela graça do batismo, assumam sua missão sacerdotal, sobretudo, naquelas realidades onde a presença dos leigos e das leigas se faz constante, como na família, no mundo do trabalho e da articulação sócio-econômica e política. Mas para isso, é necessária uma iniciação mais profunda na fé e na vivência do amor de Deus, que foi derramado em nossos corações (Rm 5,5). Mediante esse amor, podemos oferecer nossas vidas como sacrifício de suave odor. Por isso, refletir teologicamente sobre o sacerdócio real de todos os fiéis é dar uma contribuição para a Igreja e para o mundo. Parece que aí está a encruzilhada, diante da qual a Igreja precisa avançar no seu caminho de evangelização.

\section{O SACERDÓCIO REAL COMO PRESSUPOSTO DA VIDA CRISTÃ}

\author{
Por ele, vós nos chamastes \\ das trevas à vossa luz incomparável, \\ fazendo-nos passar do pecado e da morte \\ à glória de sermos o vosso povo, \\ sacerdócio régio e nação santa, \\ para anunciar por todo o mundo as \\ vossas maravilhas. ${ }^{1}$
}

1 MISSAL Romano, Prefácio dos Domingos do Tempo Comum, I. São Paulo: Paulus, 1992, p. 428. 
Estamos para festejar os 50 anos do início do Concílio Ecumênico Vaticano II, em 2012,2 e precisamos retomar as grandes conquistas que esse Concílio trouxe para a Igreja e para a humanidade. Uma delas é a compreensão da Igreja como Povo de Deus $^{3}$ e, em decorrência dessa eclesiologia, o Concílio salientou a concepção sacerdotal de todo o povo de Deus, pela graça do batismo, o que por vários séculos tinha sido deixado à margem. Dessa forma, todos os sacramentos, inclusive o sacramento da Ordem, tem como pressuposto fundamental o sacerdócio "comum de todos os fiéis", também chamado de sacerdócio real ou sacerdócio universal dos cristãos, os quais, ao seu modo, participam do único sacerdócio de Cristo. ${ }^{4}$ Esse sacerdócio representa o cumprimento da profecia do Antigo Testamento: "Vós sereis para mim um reino de sacerdotes e uma nação santa" (Ex 19,6). Justamente, é em função dessa profecia que nasce um dia, em torno de Cristo, um grupo de apóstolos e discípulos, a fim de universalizar a promessa a que Cristo deu cumprimento. Então, para se compreender a vida e a missão da Igreja, como também a índole do sacerdócio ordenado, é necessário partir do pressuposto do sacerdócio universal, do qual o sacerdócio ordenado constitui um eminente serviço, conforme a consciência que brota do Concílio Vaticano II, muito bem sintetizada pelo Papa João Paulo II, na Exortação apostólica pós-sinodal Pastores Dabo Vobis:

Para o serviço deste sacerdócio universal da Nova Aliança, Jesus chama a si, no decurso da sua missão terrena, alguns discípulos (cf. Lc 10,1-12) e, com um mandato específico e autorizado, chama e constitui os Doze, para que "estivessem com ele, e para os enviar a pregar, e para que tivessem o poder de expulsar os demônios" (Mc 3,14-15). ${ }^{5}$

As palavras do Papa João Paulo II fazem eco ao que o Concílio afirmou: "o sacerdócio comum dos fiéis e o sacerdócio ministerial ou hierárquico, apesar de diferirem entre si essencialmente, e não apenas em grau, ordenam-se um para o outro". ${ }^{6}$ Porém, ordenam-se na linha do serviço em que o sacerdócio

2 O Concílio Ecumênico Vaticano II ocorreu nos anos 1962-1965. Foi convocado pelo Papa João XXIII, aos 25 de dezembro de 1961; aberto no dia 11 de outubro de 1962; e encerrado solenemente pelo Papa Paulo VI, no dia 08 de dezembro de 1965.

3 É o tema do Capítulo II da Constituição dogmática Lumen gentium sobre a Igreja.

4 Cf. CONCÍLIO VATICANO II, Constituição dogmática Lumen gentium sobre a Igreja, n. 10.

5 JOÃO PAULO II. Exortação apostólica pós-sinodal. Pastores Dabo Vobis sobre a formação sacerdotal, n. 14.

6 CONCÍlIO VATICANO II, Constituição dogmática Lumen gentium sobre a Igreja, n. 10. 
ministerial coloca-se a disposição do sacerdócio real, numa autêntica postura de lava-pés. Não é sem razão que Susan K. Wood diz: "o sacerdócio ordenado deve ser visto na perspectiva do sacerdócio comum dos fiéis", 7 pois não é do sacerdócio ordenado que brota o sacerdócio comum dos fiéis, mas ao contrário: é dentre os membros do sacerdócio comum de todos os fiéis, que Deus escolhe quem ele quer para presidir, na pessoa de Cristo (in persona Christi), o corpo eclesial (Igreja) e o corpo sacramental (Eucaristia). Então, o sacramento da Ordem supõe os sacramentos da iniciação cristã, mesmo sendo um sacramento particular, ${ }^{8}$ uma nova intervenção divina para dar a homens escolhidos dentre o povo fiel um carisma sacerdotal específico, em vista da organização sacerdotal do Povo de Deus. Portanto, a natureza do sacerdócio na Igreja está intimamente ligada à missão de aumentar a glória de Deus e fazer progredir os homens na vida divina. ${ }^{9}$

\section{A DIMENSÃO SACERDOTAL DO AMOR (ÁGAPE)}

O progresso na vida divina, na sua extensão mais profunda, é o que os orientais chamam de "deificação", comparável ao que os místicos chamam de inabitação trinitária no homem terreno..$^{10} \mathrm{~A}$ vida divina significa a superação da oposição que atormenta a alma humana, por causa do pecado. Essa oposição, para uma teologia racionalista, situa-se na divisão entre corpo e alma. Porém, do ponto de vista bíblico, como afirma Paul Evdokimov, a divisão é muito mais profunda; é metafísica e, por isso, situa-se entre o terrestre e o celeste, entre o homem animal e o homem espiritual, entre a autonomia de cada um deles, revelando o abismo ontológico entre o batizado e o não batizado. ${ }^{11}$ Não se trata de uma oposição entre o corpo que tende para o pecado e a alma que tende para a justiça, mas de uma oposição que ultrapassa o nível da física e chega ao ser íntimo do homem,

WOOD. Susan K. El sacramento del Orden. Barcelona: Centro de Pastoral Litúrgica, 2008, p. 157.

8 Cf. CONCílIO VATICANO II. Decreto Presbyterorum Ordinis sobre o ministério da vida dos presbiteros, n. 2.

9 Cf. Ibidem.

10 Para se compreender o que é deificação, há duas obras importantes. Uma é do Ocidente europeu e outra o oriente russo: ZUBIRI, Xavier. El ser sobrenatural: Dios y la deificación en la teología paulina. Barcelona: Herder, 2008; EVDOKIMOV, Paul. L'Ortodossia. Bolonha: EDB, 2010.

11 Cf. EVDOKIMOV, Paul. L'Ortodossia. Bolonha: EDB, 2010, p. 88. 
dividindo-o em tendências opostas. Somente uma intervenção divina pode apontar uma autêntica solução. Essa solução vem no processo de salvação, em que o Pai envia o Filho para salvar a humanidade; o Filho doa o Espírito Santo; e o Espírito Santo doa o Ágape. (cf. Rm 5,5). Este transforma o ser humano em nova criatura, unificada e curada da sua divisão patológica. É por isso que Cristo veio dar cumprimento à promessa de um sacerdócio que modificasse a estrutura do ser humano, unificando seu coração para Deus, de tal forma que o homem pudesse oferecer-se, enquanto sacerdote, a si mesmo como oferta agradável. Assim, a humanidade aguardava esse dia, até que ele despontou numa aurora que iluminou o horizonte da criação para sempre: a aurora da encarnação.

A promessa de um sacerdócio extensivo a todos os filhos de Israel atravessou os séculos e só foi realizada no Novo Testamento, uma vez que era condicionada à fidelidade da aliança: "Se ouvirdes a minha voz e guardardes a minha aliança". Como a infidelidade de Israel foi notória, o que o próprio Antigo Testamento denuncia com vigor, ${ }^{12}$ a promessa não pôde ser cumprida, pois estava condicionada e a condição constituiu um obstáculo.

E foi cumprida no Novo Testamento, não por mérito humano, mas por misericórdia divina. Foi o "protagonismo" do Amor. A Nova Aliança necessitava de um coração novo, onde a fidelidade pudesse reinar. E seria inútil esperar esta atitude da capacidade humana, pois como diz Jeremias, a resposta seria sempre fatídica: "É inútil! Nós seguiremos nossos planos; cada um agirá conforme a obstinação do seu coração malvado" (Jr 18,12). Humanamente não haveria solução, pois "quando o coração é mau, as melhores leis não servem para nada". ${ }^{3}$ Os homens não poderiam mudar o seu coração. No máximo, fariam como o salmista a bater no peito, clamando o miserere:

Tem piedade de mim [...], pois reconheço as minhas transgressões e diante de mim está sempre o meu pecado [...]. Eis que eu nasci na iniquidade, minha mãe concebeu-me no pecado [...] cria em mim um coração puro, renova um espírito firme no meu peito (SI 51, 3.8.12).

Somente uma intervenção divina poderia resolver a situação dramática da existência humana, uma vez que coração significa o próprio ser humano

12 Dt 9,$7 ;$ Jr 7,25; 26.

13 VANHOYE, Albert. Sacerdotes antigos e sacerdote novo segundo o Novo Testamento. São Paulo: Academia Cristã, p. 348. 
naquilo que há de mais profundo e radical. Como diz Paul Evdokimov: "o coração é o centro que irradia e penetra na totalidade do homem, mesmo permanecendo escondido em sua misteriosa profundidade". ${ }^{14}$ Então o coração, no sentido teológico, é mais do que um centro de sensibilidade (sentido psicológico); é um centro espiritual, onde se integram todas as faculdades do espírito, compreendido como ponta de lança do ser humano na sua capacidade de comunicação transcendente, a partir da sua estrutura criacional de imagem de Deus e da visitação divina, por meio do Mistério Pascal de Cristo. Que o homem tenha sido visitado por Deus é um dado da fé, proclamado por Zacarias: Bendito seja o Senhor Deus de Israel, porque visitou o seu povo e o libertou (LC 1,68), fazendo eco ao hino de Maria, que cantou: a minh' alma engrandece o Senhor (Lc 1,46). Então, o ser humano foi imaginado por Deus no Antigo Testamento e visitado pessoalmente pelo mesmo Deus, por meio do Mistério Pascal de Jesus.

Transformar o coração significa transformar o ser humano por inteiro, até que ele se torne maleável, como argila na mão do oleiro: "Eis que como argila na mão do oleiro sereis vós, ó casa de Israel" (Jr 18,6). Essa transformação é fundada na perspectiva de uma nova aliança que não se romperia facilmente, pois a lei divina estaria escrita nas estranhas humanas: "Eu porei a minha lei no seu seio e a escreverei em seu coração" (Jr 31,32). Romper uma aliança assim é o mesmo que se autodestruir. Por isso, clamava o povo de Israel em sua liturgia: "Meu Deus, eu quero ter a tua lei dentro das minhas entranhas" (SI 40, 9). Enquanto a Lei estivesse escrita somente no livro, o homem continuaria afastado de Deus, pois o livro e o homem são entidades separadas. Desesperadamente sedento por esse dia, Jeremias buscava uma intimidade com a Palavra de Deus e, metaforicamente, tentava colocá-la em suas entranhas, que é sinônimo de coração, em seu significado mais universal e profundo:

Quando se apresentavam palavras tuas, eu as devorava: tuas palavras eram para mim contentamento e alegria de meu coração (Jr 15,16).

Mas era apenas uma metáfora, embora de longo alcance. Então, mais do que devorar a Palavra, era preciso deixar-se devorar por ela, entregando a Deus o coração, a fim de restabelecer o laço de amizade que o pecado rompeu. Nesse regime de amizade, Deus e o homem se comunicariam

14 EVDOKIMOV, Paul. L'Ortodossia. Bologna: EDB, 2010, p. 92. 
diretamente como parceiros: "Eles não terão mais que instruir seu próximo ou seu irmão, dizendo: Conhecei a Deus! Porque todos me conhecerão, dos menores aos maiores" (Jr 31,34).

E justamente a realização dessa promessa não se deu antes de Cristo, porque implicava numa luta que o homem não teria condição de enfrentar, pois corria o risco de sucumbir, não sobrando nada, nem mesmo o próprio homem para servir a Deus. A mudança do coração implica a mudança do ser humano por inteiro. Era uma luta onde deveria ocorrer a refundição do ser humano, no fogo devorador da santidade divina. Milhares de oferendas vivas, até mesmo pessoas, foram sacrificadas ao longo da história, a fim de que o homem chegasse a tal fim. E tudo foi inútil. Não seriam vítimas exteriores que fariam esse milagre. Ele só poderia realizar-se no coração humano. Isso não se faria sem uma luta dolorosa que poderia redundar numa agonia insuportável, como diz Vanhoye:

Para escrever a lei de Deus no coração do homem, uma terna emoção não bastaria. Necessitava-se de um luta terrível, uma espécie de combate com Deus, como o de Jacó (Gn 32,25-32), onde teria de se por em questão todo o ser do homem. Necessitava-se de uma agonia na qual a morte teria de ser encarada e na qual esta transformaria, finalmente, em ocasião suprema de obediência e amor, de tal maneira que o coração saísse de lá transformado. ${ }^{15}$

Jesus foi o único capacitado para enfrentar esta prova, uma vez que se apresenta pronto para o sacrifício da obediência, como diz o salmo: "Então eu disse, eis que venho para fazer a tua vontade" (SI 40,8). Aqui vemos delineada a agonia do Getsêmani, como símbolo da paixão de Cristo. Começando a entristecer-se e angustiar-se, Jesus disse aos discípulos: Minha alma está triste até a morte (Mt 26,38). E prostrado com o rosto por terra, orou: "meu Pai, se é possível, que passe de mim este cálice, contudo, não seja como eu quero, mas como tu queres" (Mt 26,39). E mais uma vez orou: "Meu Pai, se não é possível que isto passe sem que eu beba, seja feita a tua vontade" (Mt 26,41). Então, enquanto os discípulos dormiam, porque seus olhos eram pesados e seus corações estavam alienados, o coração de Jesus passava pelo crivo da transformação mais radical que um coração humano já passou em sua relação de obediência a Deus. Assim como

15 Ibid., p. 92. 
ocorreu na noite fria do nascimento do Salvador, em Belém de Judá, agora também os corações dormiam na noite escura do Getsêmani. Por isso, os apóstolos jamais suspeitavam o que se passava com Jesus: seu coração humano era totalmente refundido no coração de Deus. Agora, sim, o Filho de Deus estava pronto para enfrentar a sua hora e diz aos discípulos: podem dormir e descansar (Mt 26,45), pois aquilo por que a terra tinha esperado pelos séculos acabara de se realizar. E Jesus estava de tal forma pronto, que assumiu a paixão com a galhardia de quem assume uma nobre tarefa na vida: "Levantai-vos! Vamos" (Mt 26,46). Ele já estava de pé, os apóstolos, porém, não estavam. Isto significa que ele estava pronto para cumprir a obediência até a morte de cruz. Não havia mais um coração apavorado, mas um homem seguro e disposto a enfrentar tudo o que tinha de passar. É assim que os evangelistas mostram o Cristo depois da agonia de Getsêmani. No silêncio e nas suas poucas palavras ao longo daquelas horas dolorosas que sucederam ao Getsêmani, não demonstra medo ou constrangimento. Ele estava pronto para fazer a última travessia da sua vida terrena.

E foi assim que o Inocente assumiu o sacrifício cruento da própria vida com a audácia de um herói, enquanto com ele subiam dois condenados que não estavam preparados para o sacrifício. Eram levados à força, mas Jesus subia como alguém que ia ocupar um trono. E do trono sacrifical, ele foi colocado no seio da terra, de onde saiu vitoriosamente ressuscitado. "Assim, pois, daí para frente existe um homem novo, formado na adesão perfeita à vontade do Pai". ${ }^{16}$

Porém, nos perguntamos qual a natureza do sacrifício de Cristo, para não julgarmos que o Pai precisava do sangue de alguém, para salvar a humanidade. O Pai não precisava de sangue, precisava mostrar o amor divino - Ágape. Cristo é o próprio Ágape encarnado. Então, seu Mistério Pascal tornou viável a salvação, porque mostrou até onde Deus pode amar suas criaturas. O Pai precisava do Amor de Cristo e esse amor não foi negado. O sangue foi mera consequência, uma prova eterna de que "ninguém tem maior amor do que aquele que dá a vida pelos seus amigos" (Jo 15,13). Essa frase revela que não há nenhum amor acima do Ágape; ele é o cume do amor, o amor gratuito por excelência, o amor divino. Então, "a vida e a morte de Jesus, antes de tudo, foram epifania do amor de Deus encarnado

16 Ibid., p. 349. 
no amor humano, entrega gratuita de Deus na entrega gratuita do ser humano enamorado de Deus". ${ }^{17}$ Portanto, quem derrama sangue pelo outro, em nome de Cristo, é santo sem nenhuma dúvida.

Mas como pode alguém derramar sangue pelo outro, se isto parece ferir a lei natural? Sim, faz parte da natureza humana se proteger até as últimas consequências. Mas, agora, não estamos mais falando de natureza humana e sim de natureza divina: Ágape não é de procedência humana, mas divina. O sacrifício de Jesus não foi fruto de um esforço humano para se chegar até Deus; foi fruto de um amor divino que se derramou no ser humano. Por isso, o sacrifício de Jesus tem tudo a ver com amor. Se o amor tem uma dimensão dolorosa, não é porque o ser humano se sacrifica para chegar ao amor, como pensavam os pagãos; é porque o amor torna-se capaz de obedecer aos imperativos: amar e entregar-se, mesmo ao preço do sacrifício da própria vida. Portanto, o dinamismo sacrifical cristão parte de um princípio muito claro: Deus intervém primeiro, derramando o seu Ágape no coração humano, batizando-o no amor. Movido por esse amor (Ágape), o ser humano é capaz de também entregar-se pelo outro. É nesse momento que a lei de Deus ou a Lei do Amor, definitivamente, está escrita no coração humano, como diz Jesús Espeja Pardo:

Deus se mantém fiel ao seu projeto, e os profetas, muito sensíveis a esta aproximação benevolente de Deus, vislumbraram uma "nova aliança" em que por fim o Espírito entrará e transformará o coração humano, escreverá nele sua lei, e o povo celebrará um culto em espírito e verdade. Quando isto suceder, o sacrifício visível não só será manifestação e alimento para o compromisso ético; esse deixará de ser um empenho dos humanos para inclinar a divindade a seu favor, mas será consequência de se haver degustado a benevolência de Deus e a paixão intensa de responder historicamente a essa benevolência. ${ }^{18}$

Nesse sentido, "o sacrifício cristão se move no interior do Ágape, o amor gratuito que nos precede, nos acompanha e rejuvenesce continuamente a nossa existência". ${ }^{19}$ Se tomarmos a afirmação de Paulo de que em Deus

\footnotetext{
17 PARDO, Jesús Espeja. El ministério em La Iglesia: un cambio de perspectiva. Madri: Edibesa, 2001, p. 78.

18 Ibid., p. 92.

19 Ibid., p. 92.
} 
"vivemos, nos movemos e existimos" (At 17,28) e a compararmos com a definição de João, de que "Deus é Ágape" (1Jo 4,8), então podemos dizer com toda a certeza que em Ágape vivemos, nos movemos e existimos. Isso nos dá a garantia de, na terra, recebermos todos os dias o Ágape de Deus e alimentarmos a certeza da eternidade, como diz um prefácio litúrgico:

Em vós vivemos, nos movemos e somos. E, ainda peregrinos neste mundo, não recebemos todos os dias, as provas de vosso amor de Pai, mas também possuímos já na terra a garantia da vida futura. ${ }^{20}$

Então, já que os humanos não têm condições de transformar totalmente seu coração, agora temos um coração à nossa disposição para efetuarmos, por meio dele, nossa conversão à obediência radical à vontade do Pai.

E esse coração criado para nós, está à nossa disposição. Para que se faça efetivamente nosso e nos "aperfeiçoe", basta que sejamos daqueles que se tornam santificados ( $\mathrm{Hb}$ 10.14), aderindo a Cristo pela fé. Dessa forma - e só dessa forma - é que podemos entrar na Nova Aliança (Hb 10.16) e levar a lei de Deus gravada em nosso coração. ${ }^{21}$

Desde então, o que nos compete é realizar a refundição do nosso coração no coração de Cristo, oblativamente colocado à nossa disposição. $E$ é justamente isso que nos transforma em sacerdotes de Deus, capazes de oferecer-lhe nada menos que o nosso ser por inteiro. Esse é o sacrifício que Deus espera de todos os seres humanos.

\section{O SACERDÓCIO REAL, SEGUNDO O NOVO TESTAMENTO}

Os textos do Novo Testamento que professam ter chegado o tempo da realização da promessa antiga de um povo sacerdotal são: 1Pd 2,1-10; Ap 1,4-6; 5,10; 20,6.

O mais famoso e mais pesquisado desses quatro textos é, sem dúvida, $1 \mathrm{Pd} 2,1-10$, que levou muitos exegetas a aprofundarem a teologia do

20 MISSAL Romano, Prefácio dos Domingos do Tempo Comum, VI, São Paulo: Paulus, 1992, p. 433.

21 VANHOYE, Albert. Sacerdotes antigos e sacerdote novo segundo o Novo Testamento, $\mathrm{p}$. 348. 
sacerdócio batismal, como é o caso de John Helliot ${ }^{22}$ e Elisabeth Fiorenza Schussler. ${ }^{23}$ Por isso, vale a pena transcrever as palavras de Pedro, conforme a tradução da Bíblia de Jerusalém: ${ }^{24}$

Portanto, rejeitando toda maldade, toda mentira, todas as formas de hipocrisia e de inveja e todas as maledicências, desejai, como crianças recém-nascidas, o leite não adulterado da palavra, a fim de que por ele cresçais para a salvação, já que provastes que o Senhor é bondoso. Chegai-vos a ele, a pedra viva, rejeitada, é verdade, pelos homens, mas diante de Deus eleita e preciosa. Do mesmo modo, também vós, como pedras vivas, constituí-vos em um edifício espiritual, dedicai-vos a um sacerdócio santo, a fim de oferecerdes sacrifícios espirituais aceitáveis a Deus por Jesus Cristo. Com efeito, nas Escrituras se lê: Eis que ponho em Sião uma pedra angular, eleita e preciosa; quem nela crê não será confundido. Isto é, para vós que credes ela será um tesouro precioso, mas para os que não creem, a pedra que os edificadores rejeitaram, uma pedra de tropeço e uma rocha que faz cair. Eles tropeçam porque não creem na Palavra, para o que também foram destinados. Mas vós sois uma raça eleita, um sacerdócio real, uma nação santa, um povo de sua particular propriedade, a fim de que proclameis as excelências daquele que vos chamou para a sua luz maravilhosa, vós que outrora não éreis povo, mas agora sois o Povo de Deus, que não tínheis alcançado misericórdia, mas agora alcançastes misericórdia (1Pd 2,1-10).

Os três textos do Apocalipse são os seguintes:

A vós a graça e a paz da parte d'Aquele-que-é, Aquele-que-era e Aquele-que-vem, da parte dos sete Espíritos que estão diante do seu trono, e da parte de Jesus Cristo. A Testemunha fiel, o Primogênito dos mortos, o Príncipe dos reis da terra. Àquele que vos ama, e que nos lavou de nossos pecados com seu sangue, e fez de nós Uma

22 HELLIOT, John H. The Elect and the Holy: An Exegetical Examination of 1 Peter 2:4-10 and the Phrase Basileion Hierateuma. Leidn: Brill, 1966; São Francisco. Wipf \& Stock Publishers, 2006.

23 SCHÜSSLER, Elisabeth Fiorenza. Priester für Gott: Studien zum Herrschafts-und Priestermotiv in der Apokalypse. Münster: Aschendorff, 1972.

24 BÍBLIA de Jerusalém. Tradução, texto em língua portuguesa diretamente dos originais. Edições Paulinas: São Paulo, 1980. 
Realeza e Sacerdotes para Deus, seu Pai, a ele pertencem a glória e o domínio dos séculos dos séculos. Amém. (Ap 1,4-6)

Digno és tu de receber o livro e de abrir seus selos, pois foste imolado e, por teu sangue, resgataste para Deus homens de toda tribo, língua, povo e nação. Deles fizeste, para nosso Deus, uma Realeza e Sacerdotes; e eles reinarão sobre a terra. (Ap 5, 9-10)

Feliz e santo aquele que participa da primeira ressurreição! Sobre estes a segunda morte não tem poder; eles serão sacerdotes de Deus e de Cristo, e com ele reinarão durante mil anos. (Ap 20,6)

Esses quatro textos afirmam, sem dúvida, que a comunidade cristã é um organismo sacerdotal e que cada membro dela é, pessoalmente, sacerdote. Contudo, é necessária uma boa compreensão da dimensão sacerdotal de todo o Povo de Deus, para não cairmos na afirmação errônea da igualdade fundamental do sacerdócio para todos os fiéis, a partir do texto petrino. Para tanto, recorremos à conclusão do grande estudioso e exegeta Alberto Vanhoye:

Quanto à igualdade de todos no sacerdócio, o texto de Pedro não diz absolutamente nada. Fala, certamente, da participação de todos os crentes no sacerdócio da Igreja, mas não fala de igualdade. Ao relacionar o "organismo sacerdotal" com a "casa espiritual", sugerem, isso sim, diversos níveis de participação. Efetivamente, em uma construção, todas as pedras são parte do edifício e são solidárias umas das outras, mas nem todas elas estão no mesmo nível, nem cumprem a mesma função. Uma casa tem, necessariamente, uma estrutura diferenciada. A existência de uma hierarquia sacerdotal na igreja não está, portanto, em desacordo com a ideia de [...] (hiérateuma), tal como Pedro a apresenta em 2,4.5; pelo contrário, está implicitamente contido nela. ${ }^{25}$

Esta afirmação de Alberto Vanhoye é fruto de valiosa pesquisa que redundou numa robusta obra sobre o sacerdócio cristão na Igreja primitiva. Como exegeta, aprofundou o termo hiérateuma, que Pedro retira da tradução da Septuaginta, cujo significado aponta que a Igreja funciona como um organismo sacerdotal. ${ }^{26}$ Portanto, a diversidade de ministérios é legítima

\footnotetext{
25 VANHOYE, Albert. Sacerdotes antigos e sacerdote novo segundo o Novo Testamento. São Paulo: Academia Cristã, 2006, p. 414.

${ }^{26}$ Cf. Ibid., p. 410.
} 
e autêntica. Mas, não pode ser vista senão a partir da visão de povo sacerdotal, realização da promessa de Deus feita no Antigo Testamento e cumprida por Cristo.

Outra posição que se deve garantir no conceito de povo sacerdotal e que vem justamente do conceito de hiérateuma, é a impossibilidade de se exercer o sacerdócio cristão de maneira individual ou isolada dos demais. Nesse sentido, também afirma Vanhoye:

Um crente que se negar a cumprir esta condição e pretender aproximar-se de Deus de uma maneira individualista estará se excluindo do sacerdócio cristão. A ideia de um sacerdócio exercido por cada um, independente do conjunto do corpo, não está na perspectiva de Pedro. [...] A condição para poder apresentar a Deus uma oferta é sempre a de aceitar fazer parte da "casa espiritual" que tem seu fundamento em Jesus Cristo; não há nenhum outro "lugar sagrado" onde Deus possa ser encontrado. ${ }^{27}$

A expressão imperativa, "chegai-vos a ele", tem antes de tudo um sentido litúrgico e depois, certamente, existencial, na linha do testemunho cristão. E tem sentido litúrgico, porque, depois do batismo, a adesão à fé se expressa em primeiro plano pela participação na vida litúrgica da comunidade, como acontecia na comunidade primitiva (At 2,41ss.). ${ }^{28}$ Chegar-se a Cristo pela liturgia é reconhecer a necessidade absoluta da mediação do Filho de Deus e da união contínua com ele, pois "o organismo sacerdotal não existe, a não ser graças à adesão a Cristo ("achegando-vos a ele") e não exerce sua função de "oferecer sacrifícios", a não ser graças a Cristo ("por intermédio de Jesus Cristo")". ${ }^{29}$ Não toma parte do sacerdócio cristão quem não está unido a Cristo, desde o batismo. "Somente Cristo possui o sacerdócio em plenitude, porquanto é o único mediador". ${ }^{30}$

Essa união a Cristo, por meio da liturgia, desemboca no testemunho cristão, na medida em que Cristo, por sua paixão e ressurreição, se converteu no fundamento de novos relacionamentos entre as pessoas e no

\footnotetext{
Ibid., p. 413.

Cf. Ibid., p. 404.

29 Ibid., p. 403.

30 Ibid., p. 403.
} 
princípio de uma nova solidariedade. ${ }^{31}$ Então, é toda a existência cristã que deve ser transformada a partir da liturgia, onde reina a ação santificadora de Cristo, pelo Espírito Santo.

Convertido em "pedra viva", por sua paixão e ressurreição, Cristo adquiriu a capacidade de agregar a si outras pedras, que se transformam no contato com ele, recebem sua vida nova e ficam incorporadas a um edifício que recebe toda a consistência. ${ }^{32}$

A fé é a única condição para se fazer parte do edifício espiritual, que é Cristo. Já o testemunho, é a consequência lógica da fé e a prova de vida espiritual. "O fundamento do sacerdócio não é, portanto, mérito dos homens; tampouco a miséria dos homens constitui obstáculo à participação no sacerdócio". ${ }^{33}$ Daí, a experiência da bondade de Deus e a participação na misericórdia de Cristo de que fala Pedro. O que divide agora a humanidade é ser crente ou não ser crente. Ademais, como afirma Paulo, "não há judeu nem grego, não há escravo nem livre, não há homem nem mulher; pois todos vós sois um em Cristo Jesus" (GI 2,28).

Sem o pressuposto do sacerdócio real de todos os fiéis, que é base do conceito de Igreja Povo de Deus, vista como um organismo sacerdotal (1Pd 2.1-10) e nação de sacerdotes capazes de oferecer sacrifícios a Deus, (Ap 1,4-6; 5,10; 20,6) por causa da dignidade real e sacerdotal, fica muito difícil se compreender o mistério da Igreja.

Não há explicação humana para o fenômeno de natureza mística que leva uma comunidade inteira a realizar, em sua liturgia, a experiência mais profunda da passagem dos sinais rituais para a comunhão com Deus senão a certeza de que, por meio da presidência do ministro ordenado, cada um dos membros, exercitando seu sacerdócio batismal, chega ao coração do próprio Cristo, que eleva louvores ao Pai e nos agrega à sua ação sacerdotal. Nenhum esforço puramente humano poderia dar conta de tão grande passagem; seria insuficiente. Nessa circunstância, não conta a habilidade humana do celebrante principal, mas a sua unção sacerdotal específica, certamente exercida com piedade e adoração. Pessoas das mais variadas circunstâncias e situações culturais, diante de uma celebração autêntica,

\footnotetext{
1 lbid., p. 405.

32 Ibid., p. 405-406.

33 Ibid., p. 400.
} 
conseguem entrar na unidade que o sacramento da Páscoa de Cristo exige, porque naquela hora há uma condição que unifica toda a assembléia e a leva, por meio da beleza, à intimidade divina. Essa condição é dada pelo sacerdócio real de todos os fiéis.

E a liturgia, por sua vez, vai conduzindo cada vez mais à unidade entre as pessoas, como se já se conhecessem há muito tempo. Não há dúvida de que as pequenas comunidades suscitam experiências comuns e mais aprofundadas, e nisso há uma riqueza muito grande que influi na liturgia. Por isso, é ideal que a grande comunidade paroquial seja uma rede de pequenas comunidades, uma "comunidade de comunidades". No entanto, a experiência de Deus, de que estamos falando aqui, é feita em toda celebração, seja ela numa pequena comunidade ou numa grande catedral. Nesse sentido, o grande liturgista Josef Andreas Jungmann diz, na introdução do seu livro Missarum sollemnia:

Desde que o Homem-Deus passou por nossa terra e concluiu seus dias terrestres com o sacrifício da salvação na cruz, tomou início aquela celebração que, a partir de então, passa por todos os séculos e países como presença misteriosa de sua entrega universalmente salvífica, e que nunca cessará, até que ele volte. Em repetição infinita, ora em esplendor festivo e no meio de milhares de pessoas animadas, ora no silêncio de uma capela lateral, na simplicidade de uma pequena Igreja rural, em algum canto do qual as pessoas consagradas a Deus saem para realizar suas obras de caridade, em todo lugar realiza-se, dia após dia, o mesmo mistério. Mal separado do mercado da vida por uma parede fina, ele está no meio das pessoas que acorrem à graça divina que nele brilha, que Ihe estendem as mãos em busca de socorro, para não afundar-se na futilidade e na ausência de Deus que marcam a vida. ${ }^{34}$

O texto de um estudioso apaixonado pelo mistério da liturgia mostra o que estamos falando: uma celebração litúrgica, realizada conforme sua natureza e dentro da qualidade exigida, desafia a ciência da comunicação humana, que certamente terá de se dobrar ao mistério que a ciência não tem poder de explicar. Somente uma unção divina poderia ter como efeito

34 JUNGMANN. Josef Andreas. Missarum solemnia: origens, liturgia, história e teologia da missa romana. São Paulo: Paulus, 2009, p. 5. 
a comunhão que é própria da Eucaristia. E essa unção divina vem a ser o dom sacerdotal que Deus oferece ao povo da Nova Aliança, por meio da fé em Jesus Cristo e dos sacramentos da Igreja, ressaltando o batismo, que nos insere na vida divina e a eucaristia que alimenta continuamente nessa inserção.

\section{CONCLUSÃO}

O esforço de mostrar, por meio deste artigo, como o sacerdócio real do Povo de Deus é fundamental para a compreensão da missão cristã, levou-nos a ressaltar a graça do batismo como o pressuposto de todos os ministérios e de toda a vida sacramental da Igreja. E nesse sentido, também é pressuposto para a missão.

Porém, o batismo está inserido na iniciação cristã, que tem seu cume na eucaristia. Um povo sacerdotal é um povo eucarístico por excelência. Por isso, há na vida cristã uma dimensão sacerdotal que é dada pelo Ágape, o amor de Deus incondicionalmente oblativo, que nos é dado pelo Espírito e que nos foi doado por Cristo (Rm 5,5).

Falar de um povo sacerdotal é falar de um povo que vive no Amor e, por isso mesmo, é capaz de oferecer o sacrifício da própria vida como um ato de louvor. É um povo que, na liturgia da Igreja, entra em sintonia com o Mistério de Deus, porque Deus é Amor.

Diante do momento histórico em que vivemos, é urgente dar concretude ao projeto do Concílio Vaticano II, que trouxe à tona uma dimensão fundamental da fé cristã: o sacerdócio real do povo de Deus. Somente assim teremos condições de realizar a nova evangelização que o Papa Bento XVI, na esteira do Beato João Paulo II, tanto sonha para nossos dias. Nessa evangelização, tem de envolver-se todo o Povo da Nova Aliança, que precisa assumir, cada vez mais, sua missão sacerdotal no mundo.

\section{BIBLIOGRAFIA}

BÍBLIA de Jerusalém. Tradução, texto em língua portuguesa diretamente dos originais. São Paulo: Paulinas, 1980.

CHEVALIER, M. A. I Pierre 1,1-2. Strutucture littéraire e conséquences exegétiques. RHPR 51 (1971). 
CODY, A. History of Old Testament Priesthood. Roma: Pontifício Instituto Bíblico, 1966.

CONCÍLIO ECUMÊNICO VATICANO II. Constituição dogmática Lumen Gentium sobre a Igreja. In: DOCUMENTOS do Concílio Vaticano II (1962-1965). São Paulo: Paulus, 2001.

CONCÍLIO ECUMÊNICO VATICANO II. Decreto Presbyterorum Ordinis sobre o ministério e a vida dos presbíteros. In: DOCUMENTOS do Concílio Vaticano II (1962-1965). São Paulo: Paulus, 2001.

COPPENS, J. Le sacerdoce royal des fidèles: un commentaire de 1 Petr., II, 4-10. Au service de la parole de Dieu. Gembloux, 1969.

DIDAQUÉ, o catecismo dos primeiros cristãos para as comunidades hoje. São Paulo: Paulus, 1989.

EVDOKIMOV, Paul. L'Ortodossia. Bologna: EDB, 2010

FONTBONA, Jaume. Ministério de comunión. Barcelona: Centro de Pastoral Litúrgica, 1999.

HAMMANN, Gotfried. L'amour retrouvé: Le ministère de diacre du cristianisme primitive aos Réformateurs protestants do XVle siècle. Paris: Cerf, 1994.

HELLIOT, John H. The Elect and the Holy: An Exegetical Examination of 1 Peter 2:4-10 and the Phrase Basileion Hierateuma. Leidn: Brill, 1966; São Francisco. Wipf \& Stock Publishers, 2006.

JOÃO PAULO II; Exortação Apostólica sobre a formação dos sacerdotes Pastores Dabo Vobis. São Paulo: Paulinas, 1992.

JUNGMANN, Josef Andreas. Missarum solemnia: origens, liturgia, história e teologia da missa romana. São Paulo: Paulus, 2009, tradução do original publicado em 1962.

MISSAL Romano. Restaurado por decreto do Sagrado Concílio Ecumênico Vaticano segundo e promulgado pela autoridade do Papa Paulo VI. 6. ed. São Paulo: Paulus, 1992.

PARDO, Jesús Espeja. El ministério em La Igresia: un cambio de perspectiva. Madri: Edibesa, 2001.

VANHOYE, Albert. Sacerdotes antigos e sacerdote novo segundo o Novo Testamento. São Paulo: Academia Cristã. 2006.

VAUX, Roland. Instituições de Israel no Antigo Testamento. São Paulo: Vida Nova, 2004.

WOOD, Susan K. El sacramento del Orden. Barcelona: Centro de Pastoral Litúrgica, 2008. 